\title{
Jumping Gall Wasp, California Jumping Gall Wasp, Jumping Oak Gall, Flea Seeds Neuroterus saltatorius Edwards (Insecta: Hymenoptera: Cynipidae) ${ }^{1}$
}

\author{
Kirsten Prior and Jiri Hulcr ${ }^{2}$
}

\section{Introduction}

Neuroterus saltatorius Edwards, commonly referred to as the jumping gall wasp or the jumping oak gall, is an oak gall wasp that occurs on a variety of white oak species in North America (Figure 1). It is native to the western United States, occurring on several oak species that range from Texas to Washington State. Only one of its host plants, Quercus garryana Douglas ex Hook (Oregon or Garry oak), occurs in western Canada, largely on Vancouver Island with only two small populations on the mainland. Neuroterus saltatorius had not been historically recorded on Quercus garryana in western Canada, and was first observed by the Canadian Forest Service in 1986 (Duncan 1997). It has also been putatively introduced to several locations in the eastern United States. Where this species is not native, its populations can reach very high densities (hundreds of galls on a single leaf) causing damage on oaks in the form of mid-summer foliar scorching (Figure 2).

Like most oak gall-forming wasps (Cynipidae) this species has two generations, each of which forms morphologically distinct galls. In its more conspicuous second generation (see Life Cycle section), it produces mustard-colored, small, single galls (1-1.5 mm) (Rosenthal and Koehler 1971, Smith 1995, Russo 2006) on the underside of oak leaves. It gets its common name from the charismatic jumping behavior of the second-generation galls after they fall from the leaves mid-summer (Smith 1995). The movement is much like the well-known "Mexican jumping beans" (Cydia deshalsiana) (Lepidoptera: Tortricidae). When the tightly packed larva inside the gall moves, it creates a jumping motion, and the $1 \mathrm{~mm}$ gall can jump up to $3 \mathrm{~cm}$ (Manier and Damier 2014)! This jumping action enables the gall to lodge into the soil and leaf litter where it overwinters, protected from temperature and humidity fluctuations, and its parasitoid enemies (Smith 1995, Manier and Damier 2014).

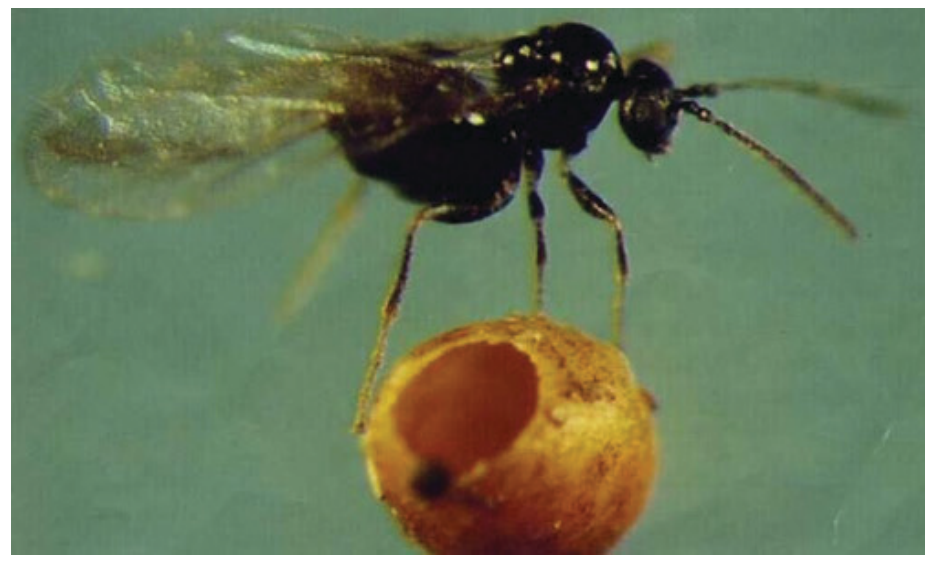

Figure 1. Gall and female wasp of the second generation of Neuroterus saltatorius. The gall is $1 \mathrm{~mm}$ in diameter.

Credits: R. Duncan, Natural Resources Canada

1. This document is EENY663, one of a series of the Department of Entomology and Nematology, UF/IFAS Extension. Original publication date July 2016. Visit the EDIS website at http://edis.ifas.ufl.edu. This document is also available on the Featured Creatures website at http://entnemdept.ifas.ufl.edu/ creatures/.

2. Kirsten M. Prior, Department of Biological Sciences, Binghamton University (State University of New York); and Jiri Hulcr, assistant professor, School of Forest Resources and Conservation; UF/IFAS Extension, Gainesville, FL 32611. 


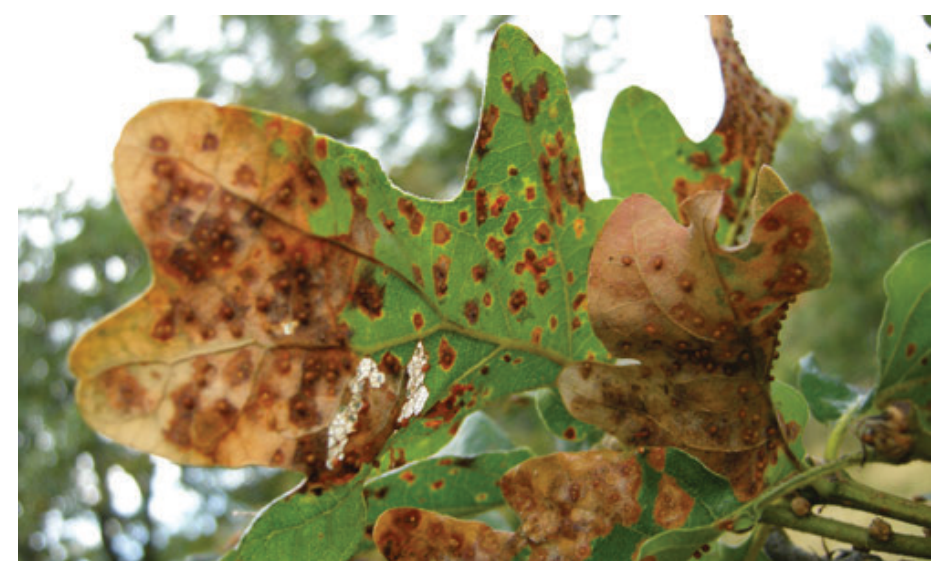

Figure 2. Foliar damage caused by the second generation of Neuroterus saltatorius in its introduced range (Victoria, British Columbia, Canada).

Credits: Kirsten Prior, Binghamton University

Another reason why this tiny gall garners attention is because it can cause significant mid-summer foliar scorching on oaks (Figure 2). Foliar necrosis occurs around the site of gall attachment, and when the number of galls on a leaf is high the entire leaf can brown. In some cases, whole trees become infested, and branch dieback or premature defoliation occurs (Figure 3). Where this species is found in the western United States, the numbers of galls on leaves is not usually high. Damage is rarely reported, and when infestations occur, infested trees are often in isolation (Smith 1995, Schick 2003, Prior and Hellmann 2013). This species has been introduced into new locations, such as to the San Juan Islands in Washington State and Vancouver Island, British Columbia in Canada. The Canadian Forest Service first detected this species in 1986 just north of the city of Victoria (Duncan 1997). In its introduced range, it occurs at very high densities on trees; whole patches of trees are often infested, and infestations are consistently high from year to year (Smith 1995, Duncan 1997, Prior and Hellmann 2013). On Vancouver Island and the San Juan Islands, it is considered a threat to a rare oak savanna ecosystem (Duncan 1997, Prior and Hellmann 2010).

\section{Synonymy}

Cynips saltatoria Riley (1910)

Cynips saltitans Dodge (1876)

Cynips saltatorius Edwards (1874)

Neuroterus decipiens Kinsey (1922) (first generation)

(from Kinsey 1922, McCracken and Egbert 1922, Rosenthal and Koehler 1971)

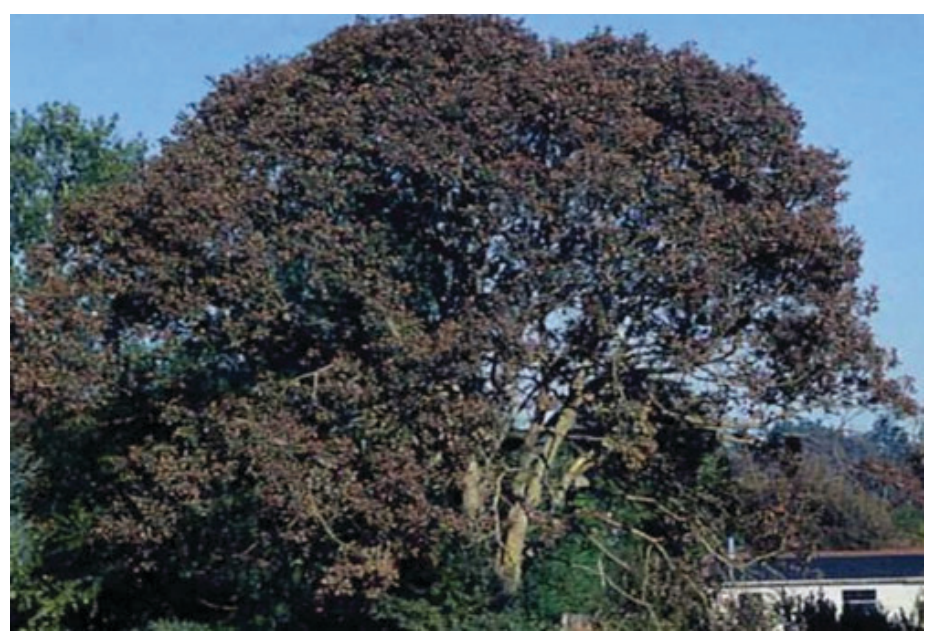

Figure 3. Infested Quercus garryana tree and mid-summer foliar damage in Victoria, British Columbia, Canada.

Credits: R. Duncan, Natural Resources Canada

\section{Distribution}

Neuroterus saltatorius is native to several states in the western United States, including California, west Texas, Oregon, and Washington (Allen 1910, McCraken and Egbert 1992, Russo 2006).

Before 1986, it had not been recorded in western Canada, with the first record of this species popping up in an urban park just north of Victoria, British Columbia (on Vancouver Island). Over the next ten years, the Canadian Forest Service tracked its spread to oak patches more north on the island, and to the surrounding Juan de Fuca and San Juan (Washington State) islands (Duncan 1997). After this detection, extensive surveys were conducted in this region again in 2007 and 2008, revealing that Neuroterus saltatorius now occurs to the northernmost location of oak on Vancouver Island (Prior and Hellmann 2013).

Infestations have also recently been recorded in several eastern states, including Missouri (missouribotanicalgarden.org 2016), Michigan (Russell and Smith 2013), Indiana, Kentucky (Marshall 1999), Minnesota (dnr.state.mn.us 2016), and Wisconsin (Guthmiller 2015). However, it is unclear if these infestations have surfaced from low-lying endemic populations, are introduced populations from the west, or if they are even truly Neuroterus saltatorius. According to Allen (1910), Neuroterus saltatorius was described from specimens from the western United States. He suggests that, while there are historical records of this species from several states in the east, these records may be other species with the true species being from the west. Thus, it is yet to be confirmed if this species is either native or introduced to the eastern United States. 


\section{Description}

Neuroterus saltatorius has two generations that are morphologically distinct. The first generation is the sexual or gamic generation (Figure 4), and the second generation is the asexual or agamic generation (Figure 5). Listed below are descriptions for those life history stages and galls that have been previously described.

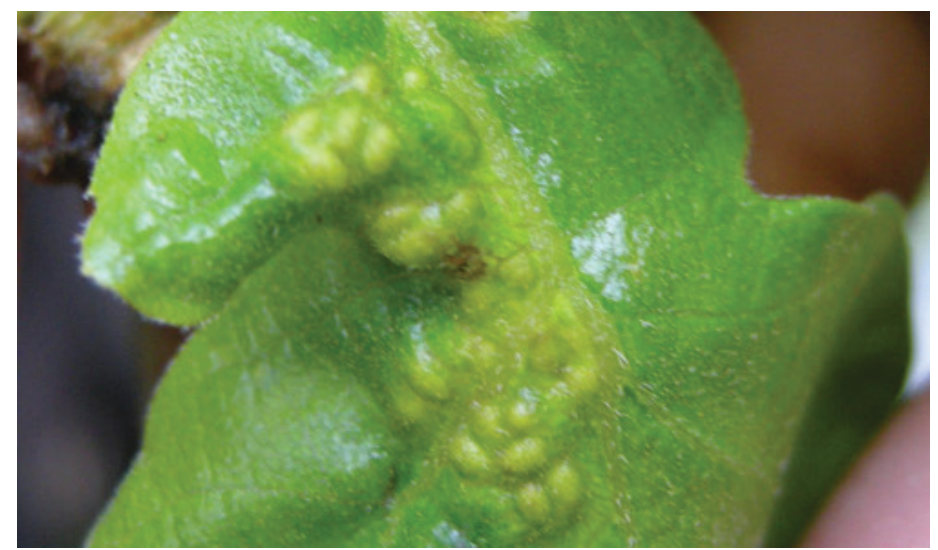

Figure 4. First or gamic (sexual) generation foliar cluster galls.

Credits: Kirsten Prior, Binghamton University

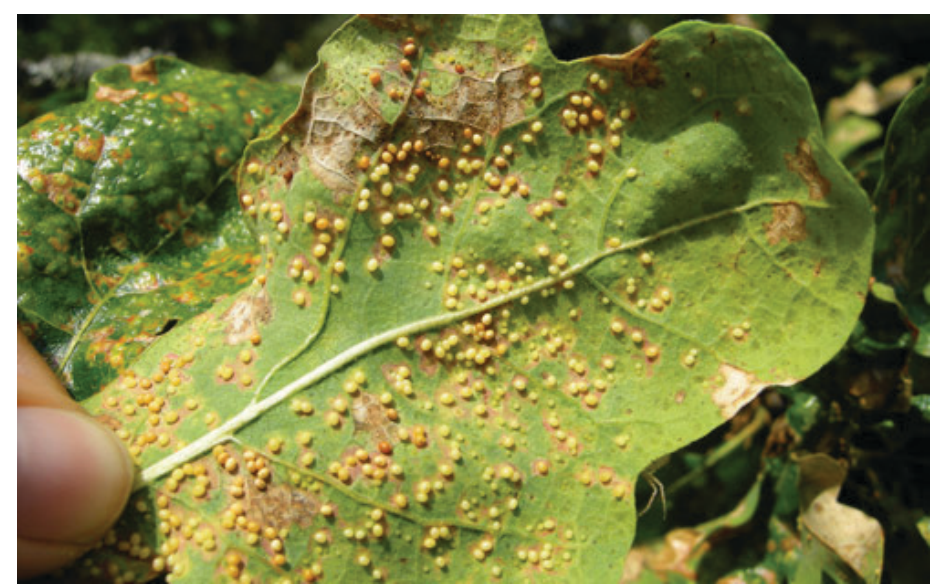

Figure 5. Second or agamic (female only) generation galls.

Credits: Kirsten Prior, Binghamton University

\section{Egg}

[agamic] small, white oval, $0.2 \mathrm{~mm}$ long (Duncan 1997).

\section{Larva}

[agamic] cream-colored with dark mandibles, curled in a $\mathrm{C}$ shape inside the gall, fully grown larva is $\sim 1.5 \mathrm{~mm}$ long (Duncan 1997).

\section{Pupa}

[agamic] cream colored, $1.5 \mathrm{~mm}$ long, similar in appearance to adult (Duncan 1997).

\section{Gall}

[gamic] non-detachable cluster galls, less than $2 \mathrm{~mm}$ long and $1 \mathrm{~mm}$ wide. At first, galls are green, and then become brown as they mature. The swelling occurs on the upper and lower surfaces of the leaf (Kinsey 1922, Rosenthal and Koehler 1971) (Figure 4).

[agamic] small $(0.75-1.5 \mathrm{~mm})$ mustard colored sub-spherical gall, finely striate, single-chambered, larval cell occupies the whole interior of gall, easily detachable from leaf (Allen 1910, McCracken 1992, Duncan 1997) (Figure 5).

\section{Adult}

[agamic female] the head is brown-black, subopaque, with minute grooves, antennae are 13-segmented, the thorax is brown with the posterior margin slightly notched, the abdomen is black, legs are reddish brown, wings are hyaline, and the total length is $0.75 \mathrm{~mm}$ (McCracken 1922) (Figure 1).

\section{Life Cycle}

Cynipid gall wasps have two generations, alternating between a sexual generation (gamic) and an asexual parthenogenic generation (agamic). Females of the agamic generation of Neuroterus saltatorius emerge in the early spring and oviposit into developing leaf tissue in closed buds. Gamic galls start to develop several weeks after oviposition. Peak flight of the gamic generation has been recorded as mid-April in California (Rosenthal and Koehler 1971) and mid-May on Vancouver Island (Smith 1995). At this time, male and female adults emerge with their flight occurring for two weeks. After mating, a gamic female will lay up to 70 eggs on the lower surface of the leaf (Duncan 1997). The agamic galls start to form 3-4 weeks after oviposition. Agamic galls develop on leaves from early summer and drop from the leaves as early as mid-summer to as late as early fall, with various stages of development found in galls on a single leaf (Rosenthal and Koehler 1971, Smith 1995). After the gall dislodges from the leaf and drops to the ground, larvae pupate within galls in the leaf litter in the fall and overwinter as adults within galls. Agamic females emerge in the spring (Rosenthal and Koehler 1971, Smith 1995). Alternation of the two generations occurs in an annual cycle.

\section{Hosts}

Neuroterus saltatorius has been recorded on several species in the white oak group in its native range including: Quercus lobata Née (valley oak), Quercus douglasii Hook. \& Arn. (blue oak), Quercus garryana Douglas ex Hook. (Oregon or 
Garry oak), Quercus dumosa Nutt. (California scrub oak), Quercus arizonica Sarg. (Arizona white oak), and Quercus virginiana Mill. (live oak).

Quercus garryana is the only white oak in its introduced range in western Canada. In the east, it has been putatively documented on Quercus alba L. (white oak), Quercus macrocarpa Michx. (burr oak), Quercus stellata Wangenh. (post oak), and Quercus virginiana Mill. (live oak).

\section{Ecology}

Parasitoid wasps (Hymenoptera: Chalcidoidea) are the main enemies that attack Neuroterus saltatorius. Nine species have been described from collections of the second generation gall in its native range in the western United States and its introduced range on Vancouver Island: Ormyrus distinctus Fullaway (Ormyridae), Amphidocius schickae Heydon \& Boucek (Pteromalidae), Amphidocius n. sp. (Pteromalidae), Mesopolobus longicaudae Doganlar (Pteromalidae), Dibrachys cavus Walker (Pteromalidae), Aprostocetus pattersonae Fullaway (Eulophidae) (Figure 6), Aprostocetus verrucarii Balduf (Eulophidae), Aprostocetus n. sp. (Eulophidae), Brasema sp. (Eupelmidae). One inquiline that is not a chalcid (i.e., a non-parasitoid inhabitant of a gall), Synergus sp. (Cynipidae: Synergini) (Sopow 1992, Smith 1995, Prior and Hellmann 2013), was also found. Mesopolobus longicaudae, Aprostocetus verrucarii, and Amphidocius n. sp. have been reared from the first generation (Smith 1997).

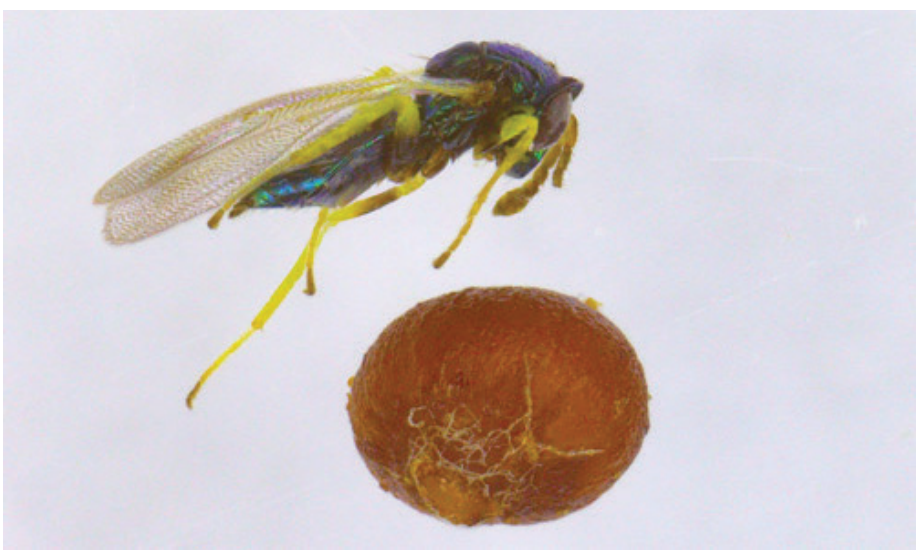

Figure 6. The parasitoid wasp Aprostocetus pattersonae (Chalcidoidea: Eulophidae) that emerged from a gall of Neuroterus saltatorius. Credits: Kirsten Prior, Binghamton University

Parasitoid species overlap in distribution in the native range in the western United States and in the introduced range in British Columbia, Canada (Smith 1995, Prior and Hellmann 2013). All but one of these species, Amphidocius schickae, has been reared from other species of cynipid gallwasps on Vancouver Island and in Washington State (Smith 1995). Thus, when Neuroterus saltatorius was introduced to Vancouver Island, Amphidocius schickae may have been introduced with it, while the other parasitoid species could have switched to attacking Neuroterus saltatorius from alternative cynipid hosts in the introduced range. Parasitoid rates are lower in the introduced range compared to the native range, suggesting that outbreaks in the introduced range may be partially explained by lower parasitoid attack rates (Prior and Hellmann 2013).

Other types of enemies have been observed as predators on galls, including the European earwig, Forficula auricularia L., and a ground beetle Pterostichus melanarius Illiger. Birds can also eat galls, but cause relatively low mortality. Fungal pathogens have been known to infect oak gall-formers, but have not been reported to infect Neuroterus saltatorius (Liu 1991).

Increased host plant susceptibility may play a role in the outbreaks of Neuroterus saltatorius in its introduced range. While most trees in a patch of oaks are infested in the introduced range, in the native range highly infested trees are rare and often surrounded by a sea of uninfested trees. Higher failed gall induction and higher mortality of gall-formers has also been recorded in the native range compared to the introduced range on Vancouver Island (Prior and Hellmann 2013) (Figure 7).

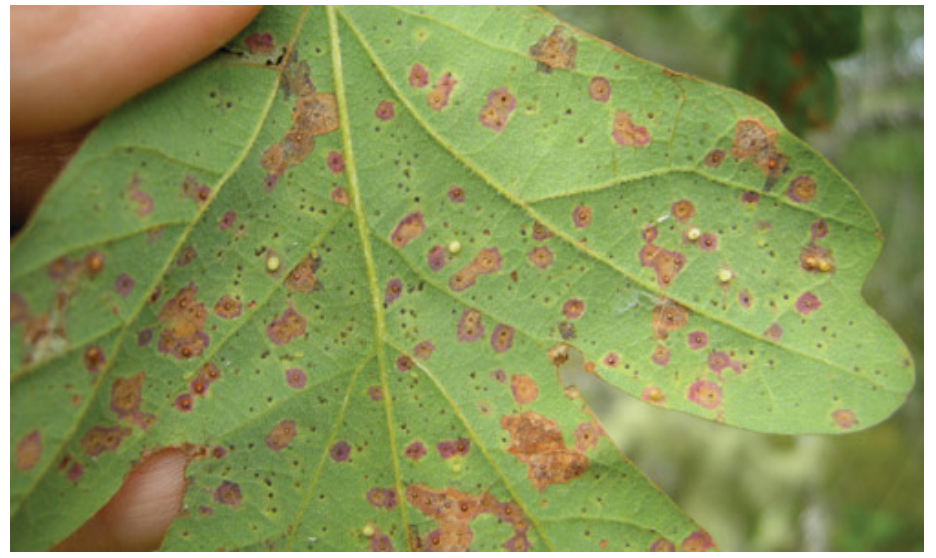

Figure 7. Failed gall induction on trees in the native range in southern Puget Sound, Washington.

Credits: Kirsten Prior, Binghamton University

Neuroterus saltatorius is also sometimes affiliated with fungal plant pathogens, such as Discula umbrinella Sutton [Berk \& Broome] in the West that causes similar foliar damage to the gall-former. However, little is known about if or how these species are affiliated (Duncan 1997).

\section{Damage}

Little damage is caused by the first generation of the gall wasp. In the second generation, the damage is also minimal when this species occurs in low abundance with 
little damage to leaves. It is when this species is in high abundance in its second generation that it can cause more significant damage. Mid-summer, foliar necrosis or scorching occurs on leaves, scorching whole trees, and leaves can prematurely fall from the tree (Duncan 1995, www. missouribotanicalgarden.org 2016). Heavy infestations can cause die back of twigs and branches as well as potentially facilitate tree death by increasing tree vulnerability to disease and secondary insects (Duncan 1997). In its introduced range on Vancouver Island, Neuroterus saltatorius was also shown to have an impact on a native, specialist, threatened butterfly, the Propertius duskywing, Erynnis propertius Scudder \& Burgess (Lepidoptera: Hesperiidae) by reducing nutrients in the leaves fed on by the caterpillars (Prior and Hellmann 2010). Given that oaks are major arboriocultural trees, damage by this species sometimes invokes widespread public concern.

\section{Management}

Keeping trees healthy by including activities such as mulching, watering during dry periods, avoiding injury, and fertilizing in the spring may help to reduce infestations. However, given that the gall-former likely does not seriously injure most trees, insecticidal sprays are not recommended (Duncan 1997, www.missouribotanicalgarden.org 2016). Good garden sanitation can also help; for example, raking up fallen leaves post gall drop. After time, natural enemies may catch up to introduced populations; however, if they do they will only be able to partially control outbreak populations (Prior and Hellmann 2013).

\section{Selected References}

Allen JA. 1910. Bulletin of the American Museum of Natural History. Vol. XXVII. New York: Published by order of the Trustees.

Duncan RW. 1997. Jumping gall wasp. Forest Pest Leaflet (Fo 29-6/80-1997E). Natural Resources Canada, Canadian Forest Service, Pacific Forestry Centre, British Columbia, Canada.

Guthmiller M. 2015. Southern Wisconsin Forest Health Update. Wisconsin Department of Natural Resources, Forest Health Protection Unit, 12. http://dnr.wi.gov (6 June 2016)

Kinsey, AC. 1922. The gall wasp genus Neuroterus (Hymenoptera). Indiana University Studies 58, pp. 150.

Liu T. 1991. The association between fungal endophytes and the Jumping gall wasp (Neuroterus saltatorius) on
Garry oak (Quercus garryana). Masters thesis. University of Oregon, Eugene, Oregon, US.

Marshall P. 1999. A jumping gall invades southern Indiana forests. Illinois Department of Natural Resources, Division of Forestry, 8 (31 March 2016)

McCracken I, Egbert D. 1922. California gall-making Cynipidae with descriptions of new species plates I and II. Stanford University Publications. University Series. Biological Sciences Vol III Number 1. Standford University Press.

Manier S, Deamer D. 2014. Jumping galls: A novel mechanism for motility. Journal of Insect Behavior 27: 716-721.

Minnesota Department of Natural Resources, Jumping oak gall. http://dnr.state.mn.us (6 June 2016).

Missouri Botanical Garden: Gardens and gardening, Jumping oak galls. http://www.missouribotanicalgarden.org (31 March 2016)

Prior KM, Hellmann, JJ. 2010. Impact of an invasive oak gall wasp on a native butterfly: A test of plant-mediated competition. Ecology 91: 3284-3293.

Prior KM, Hellmann JJ. 2013. Does enemy loss cause release? A biogeographical comparison of parasitoid effects on an introduced insect. Ecology 94: 1015-1024.

Rosenthal SS, Koehler CS. 1971. Heterogony in some gall-forming Cynipidae (Hymenoptera) with notes on the biology of Neuroterus saltatorius. Annals of the Entomological Society of America 64: 565-570.

Russell J, Smith J. 2013. Michigan State University Extension Jumping oak gall causing damage to white oak. http:// msue.anr.msu.edu (6 June 2016).

Schick K. 2002. Cynipid-induced galls and California oaks. Fremontia 30: 15-18.

Smith JL. 1995. Life history, survivorship, and parasitoid complex of the jumping gall wasp, Neuroterus saltatorius (Edwards) on Garry oak, Quercus garryana Douglas. Masters thesis. University of Victoria, Victoria, British Columbia, Canada. 
Sopow S. 1992. Parasitoids and predators of the jumping gall wasp, Neuroterus saltatorius in the Capital Regional District. Unpublished Report. Pacific Forestry Centre, Natural Resources, Canada. 